\title{
Deprem Yönetmeliklerine Göre Sakarya İli Genelinde Yapılan Proje ve İmalat Hataları
}

\author{
${ }^{1}$ Adil Altundal ${ }^{* 2}$ Hüseyin Kasap ve ${ }^{* 3}$ Abdullah Sever \\ ${ }^{1}$ Mühendislik Fakültesi, Sakarya Üniversitesi İnşaat Mühendisliği Bölümü, Türkiye
}

\begin{abstract}
In this study, the usability of commonly used unidirectional toothed (asmolene) floorings in earthquake zones is analysed and 40 randomly selected buildings in Sakarya are examined according to both static - reinforced concrete projects and application phases according to DBYBHY 2007, TBDY 2018 and TS500. Also, forms including regulation articles of each building are arranged, the rates of mistakes made are calculated and compared with the studies conducted in other provinces. The purpose of this study is to determine the extent to which the boundary conditions in earthquake regulations are complied with during the project and construction phases and how much the project were complied with during the construction phases, and what need to be done to eliminate the detected defects.
\end{abstract}

Keywords: Manufacturing defects, Project defects, DBYBHY 2007, TS 500, TBDY 2018, Sakarya

\section{Giriş}

Türkiye, jeolojik olarak dünya üzerinde en aktif deprem bölgelerinden Himalaya - Alp Deprem Kuşağı'nın tam ortasında yer alan ve tarihinden bu yana çeşitli bölgelerinde birçok kez deprem yaşamış bir ülkedir. Ülke topraklarının tamamı deprem etkisi altında bulunmakta ve nüfusun önemli bir bölümü de deprem riskinin yüksek olduğu bölgelerde hayatını sürdürmektedir. Özellikle yakın zamanda meydana gelen 1999 İzmit ve Düzce depremlerinde, 2011 Van depreminde can ve mal kayıpları depreme dayanıklı yapı tasarımının önemini bir kez daha göstermiştir. Bunun sonucu olarak öncelikle yapılarda meydana gelen hasarları en az seviyeye düşürebilmek amacı ile deprem yönetmeliklerinde değişiklikler yapılmıştır. Yakın zamanda Deprem Bölgelerinde Yapılacak Binalar Hakkında Yönetmelik 2007 (DBYBHY 2007) ve son olarak Türkiye Bina Deprem Yönetmeliği (TBDY 2018) 2019 da yürürlüğe girmiş̧tir.

Deprem, yerkabuğu içerisindeki deformasyonlar ve kırılmalar sebebiyle aniden ortaya çıkan titreşim hareketlerinin belirli dalgalar halinde yayılması ve bu yayılan dalgaların geçtikleri ortamları ve yeryüzünü sarsması olayıdır. Ülkemizin deprem ülkesi olduğu göz önüne alındığında yapıların projelendirilmesinde ve imalatında mimarlar ve mühendislere büyük görevler düşmektedir. Bu konuda yapı tasarımları deprem yönetmeliğine uygun, herhangi bir depremde can ve mal kaybı olmayacak şekilde emniyet, ekonomi ve estetik koşullar optimum olacak şekilde projelendirilmelidir. Yapıların uygulamaları da projelerine uygun olmalıdır.

2007 deprem yönetmeliğine göre 1. derece deprem bölgesinde bulunan ve 1999 Marmara depreminin en çok hasar gören illerinden olan Sakarya özellikle zemin kalitesi açısından da kötü sayılacak bir konumdadır. Tüm bu koşullardan dolayı deprem hassasiyeti göz önüne 
alınmalı, çıkar ilişkisi ve daha fazla para kazanma hırsı olmaksızın yapılar can ve mal güvenliği korunacak şekilde projelendirilmeli ve uygulanmalıdır. Yap1 imalatındaki en önemli hususlardan birisi Yönetmeliklere uygun olarak yapılan yapıların, imalat sırasında projesine uygun olarak imal edilmesidir. Bu amaçla bu çalışma yapılmış, yapıların proje ve uygulama aşamalarındaki hata oranları deprem yönetmeliklerine göre belirlenmiştir.

TS500, DBYBHY 2007 ve TBDY 2018 yönetmeliklerinde yapıların süneklik düzeyi koşulları ve taşıyıcı betonarme yapı elemanları olan temel, kolon, kiriş, perde ve döşemelerin hem kesit şartları hem de donatı yerleşim koşulları sınır değerleriyle belirtilmiştir. Yapılan her bir binanın bu sınır şartlara uyma zorunluluğu vardır.

\subsection{Literatürde Yapılan Çalışmalar}

İnşaat Mühendisi Zihni Lort tarafından KTÜ Fen Bilimleri Enstitüsü yüksek lisans tezi olarak yapılan bu çalışmada Ankara ilinde seçilen 30 adet binanın proje ve yapım aşamalarında DBYBHY 2007 yönetmeliğine göre karşılaşılan hatalar gözlemlenmiştir. Yapılan bu çalışmada ilk olarak depremle ilgili genel bilgilerden bahsedilmiş depreme dayanıklı yapı tasarımında mimari projede uyulması gereken şartlar ile ilgili bilgiler verilmiş daha sonra taşıyıcı yapı elemanları ile ilgili konulardan söz edilmiş ve Ankara ili genelinde yapılan proje ve imalat hatalarına yer verilmiştir.

İnşaat Mühendisi Çiğdem Çalık tarafından KTÜ Fen Bilimleri Enstitüsü yüksek lisans tezi olarak yapılan bu çalışmada Trabzon ilinde seçilen 30 adet binanın proje ve yapım aşamalarında DBYBHY 2007 yönetmeliğine göre karşılaşılan hatalar gözlemlemiştir. Yapılan bu çalışmada ilk olarak depremle ilgili genel bilgilerden bahsedilmiş, depreme dayanıklı yapı tasarımında mimarı projede uyulması gereken şartlar ile ilgili bilgiler verilmiş daha sonra taşıyıı yapı elemanları ile ilgili konulardan söz edilmiş ve Trabzon ili genelinde yapılan proje ve imalatlardaki hata oranlarına yer verilmiştir.

İnşaat Mühendisi Serkan Geçici tarafından yapılan bu çalışmada Balıkesir ilinde seçilen 30 adet binanın proje ve yapım aşamalarında DBYBHY 2007 yönetmeliğine göre karşılaşılan hatalar gözlemlemiştir. Yapılan bu çalışmada ilk olarak depremle ilgili genel bilgilerden bahsedilmiş, depreme dayanıklı yapı tasarımında mimarı projede uyulması gereken şartlar ile ilgili bilgiler verilmiş daha sonra taşıyıcı yapı elemanları ile ilgili konulardan söz edilmiş ve Balıkesir ili genelinde yapılan proje ve imalatlardaki hata oranlarına yer verilmiştir.

İnşaat Mühendisi Kadir Yunus Mergen tarafından yapılan bu çalışmada Yalova ilinde seçilen 30 adet binanın proje ve yapım aşamalarında DBYBHY 2007 yönetmeliğine göre karşılaşılan hatalar gözlemlenmiştir. Yapılan bu çalışmada ilk olarak depremle ilgili genel bilgilerden bahsedilmiş, depreme dayanıklı yapı tasarımında mimari projede uyulması gereken şartlar ile ilgili bilgiler verilmiş daha sonra taşıyıcı yapı elemanları ile ilgili konulardan söz edilmiş ve Yalova ili genelinde yapılan proje ve imalatlardaki hata oranlarına yer verilmiştir.

İnşaat Mühendisi Buğra Bozkurt tarafından yapılan bu çalışmada Kocaeli ilinde seçilen 40 adet binanın proje ve yapım aşamalarında DBYBHY 2007 yönetmeliğine göre karşılaşılan hatalar gözlemlenmiştir. Yapılan bu çalışmada ilk olarak depremle ilgili genel bilgilerden bahsedilmiş, DBYBHY 2007 VE TS500'de bulunan kurallardaki uyumsuzluklar tespit edilip işlenmiş daha sonra taşıyıcı yapı elemanları ile ilgili konulardan söz edilmiş ve Kocaeli ili genelinde yapılan proje ve imalatlardaki hata oranlarına yer verilmiştir. 


\section{Materyal ve Çalışmanın Metodu}

Sakarya ilinde yapımı gerçekleştirilen ve rastgele seçilen 40 adet yapının hem statik-betonarme projeleri hem de sahada imalat aşamaları incelenmiştir. Her yapıya ait yapı formları hazırlanmış ve yönetmelik maddelerine göre formlar düzenlenmiştir. İncelemeler sonucu proje ve imalat aşamalarındaki hatalar formlar üzerine işlenerek toplamda yapılan hataların yüzdeleri hesaplanmıştır. Projeler yapı denetim firmasından elde edilmiştir.

\section{Deprem Bölgelerinde Tek Doğrultuda Dişli (Asmolen) Döşemelerin Kullanılabilirliği}

Dişli döşeme sistemlerinin bir çeşidi olan asmolen döşeme sistemleri, kirişli plak döşeme sistemlerine göre kiriş yükseklikleri ve döşeme kalınlıkları genellikle daha az olan döşemelerdir. Asmolen döşemeler, ana kirişlere tek doğrultuda ya da bazı durumlarda iki doğrultuda nervür adı verilen kirişciklerin bağlandığı, nervür aralarına da dolgu malzemesi olarak asmolen delikli tuğla, gaz beton, boşluklu beton briket gibi malzemelerin konulduğu, genellikle mimari açıdan tercih edilen bir sistemdir. Kullanılan dolgu malzemesinin adına referansla bu tip yapılara asmolen döşeme sistemli yapılar denir. Taşıyıcı sistemleri bakımından bu sistemler betonarme çerçeveli sistemlerin bir alt grubu olarak nitelendirilebilir. Statik açıdan dezavantajları çok olan asmolen döşemeli sistemler genel olarak mimari tercihler nedeniyle ülkemizde de yaygın olarak kullanılmaktadır.

DBYBHY 2007'nin 2.5.1.4. maddesine göre: Perde içermeyen kirişsiz döşemeli betonarme sistemler ile kolon ve kirişleri 3.3.3.4. ve 3.5.'te verilen koşullardan herhangi birini sağlamayan dolgulu veya dolgusuz dişli ve kaset döşemeli betonarme sistemler, süneklik düzeyi normal sistemler olarak göz önüne alınacaktır.

DBYBHY 2007'nin 2.5.1.5. maddesine göre ise: Birinci ve ikinci derece deprem bölgelerinde taşıyıcı sistemi sadece çerçevelerden oluşan binalarda süneklik düzeyi yüksek taşıyıcı sistemlerin kullanılması zorunludur diye belirtilmektedir.

DBYBHY 2007'nin 2.5.1.6. maddesinde de: Perde içermeyen süneklik düzeyi normal taşı1c1 sistemlere, sadece üçüncü ve dördüncü derece deprem bölgelerinde, 2.5.1.4.'te tanımlanan betonarme binalarda $\mathrm{H}_{\mathrm{N}} \leq 13 \mathrm{~m}$ olmak koşulu ile yapılabilir.

Sonuç olarak DBYBHY 2007'ye göre 1. ve 2. derece deprem bölgelerinde perdesiz olarak sadece çerçeve sistemden oluşturularak projelendirilen asmolen döşemeli sistemler yine DBYBHY 2007'de verilen 3.3, 3.4. ve 3.5. kolon, kiriş, kolon-kiriş birleşim bölgesi yüksek süneklik şartlarından herhangi birini sağlamadığı takdirde süneklik düzeyi normal sistemler olarak tanımlanırlar. Bu şartlar altında 1. ve 2. derece deprem bölgelerinde süneklik düzeyi yüksek sistemlerin kullanılması zorunlu olduğundan perdesiz asmolen döşemeli sistemler kullanilamaz.

TBDY 2018'de tek doğrultuda dişli asmolen döşemeli sistemler süneklik düzeyi sınırlı sistemler olarak belirtilmiştir.

TBDY 2018'in 4.3.4.3. maddesine göre: Deprem etkilerinin tamamı moment aktaran süneklik düzeyi sınırlı betonarme çerçevelerle karşılanan taşıyıcı sistemler sadece DTS=3 ve DTS=4 olan binalarda kullanılacaktır. Dolgulu (asmolen) veya dolgusuz tek doğrultulu dişli döşemeli 
betonarme çerçevelerden oluşan taşıyıcı sistemler de, perde içermedikleri takdirde, süneklik düzeyi sınırlı taşıyıcı sistemler olarak sınıflandırılacak ve sadece DTS=3 ve DTS=4 olan binalarda kullanılacaktır. Bu tür taşıyıcı sistemler, süneklik düzeyi yüksek betonarme bağ kirişli (boşluklu) ve/veya boşluksuz perdeler veya süneklik düzeyi yüksek çelik dışmerkez ve/veya merkezi çaprazlı çerçeveler ile birlikte düzenlenerek süneklik düzeyi karma sistemler olarak yapilabilir.

TBDY 2018'in 4.3.4.1. maddesinde: $D T S=1 \mathrm{a}, \mathrm{DTS}=2 \mathrm{a}, \mathrm{DTS}=3 \mathrm{a}$ ve $\mathrm{DTS}=4 \mathrm{a}$ olarak siniflandırılan binalarda ve BYS $\leq 6$ olan ve DTS=1a ve DTS=2a olarak siniflandirilan binalarda süneklik düzeyi sınırlı taşıyıcı sistemler kullanılamaz.

TBDY 2018'in 4.3.4.1. maddesinde: Betonarme ve çelik süneklik düzeyi karma taşıyıcı sistemlerde, süneklik düzeyi yüksek bağ kirişli (boşluklu) veya boşluksuz betonarme perdeler ile merkezi, dışmerkez veya burkulması önlenmiş çelik çaprazlı çerçevelerin tabanında deprem yüklerinden meydana gelen devrilme momentlerinin toplamı, binanın tümü için deprem yüklerinden tabanda meydana gelen toplam devrilme momentinin \% 75 'inden az olmayacaktır:

Sonuç olarak TBDY 2018'de tek doğrultuda dişli (asmolen) döşemeli sistemlere katı kurallar ve kısıtlamaların getirildiğini görmekteyiz. Bu yönetmelikte de asmolen döşemeli sistemlerde perde zorunluluğu ön planda tutulmuş ve deprem yüklerinden meydana gelen devrilme momentlerinin en az \% 75'ini perdelerin karşılaması gerektiği belirtilmiştir.

Sakarya genelinde incelenen 40 adet binanın 12 tanesi tek doğrultuda dişli (asmolen) döşemeye sahiptir. İncelemelerde bu binalardan 6 tanesinin tasarım aşamasında perdesiz sadece kolonkiriş çerçeve sistemden oluşturulduğu gözlemlenmiştir. Bu binalar hem DBYBHY 2007 hem de TBDY 2018 deprem yönetmeliklerine aykırıdır. Şekil 1.'de Sakarya'da uygulanmış betonarme perde içermeyen 2 katlı asmolen döşemeli bir proje örneği gösterilmiştir.

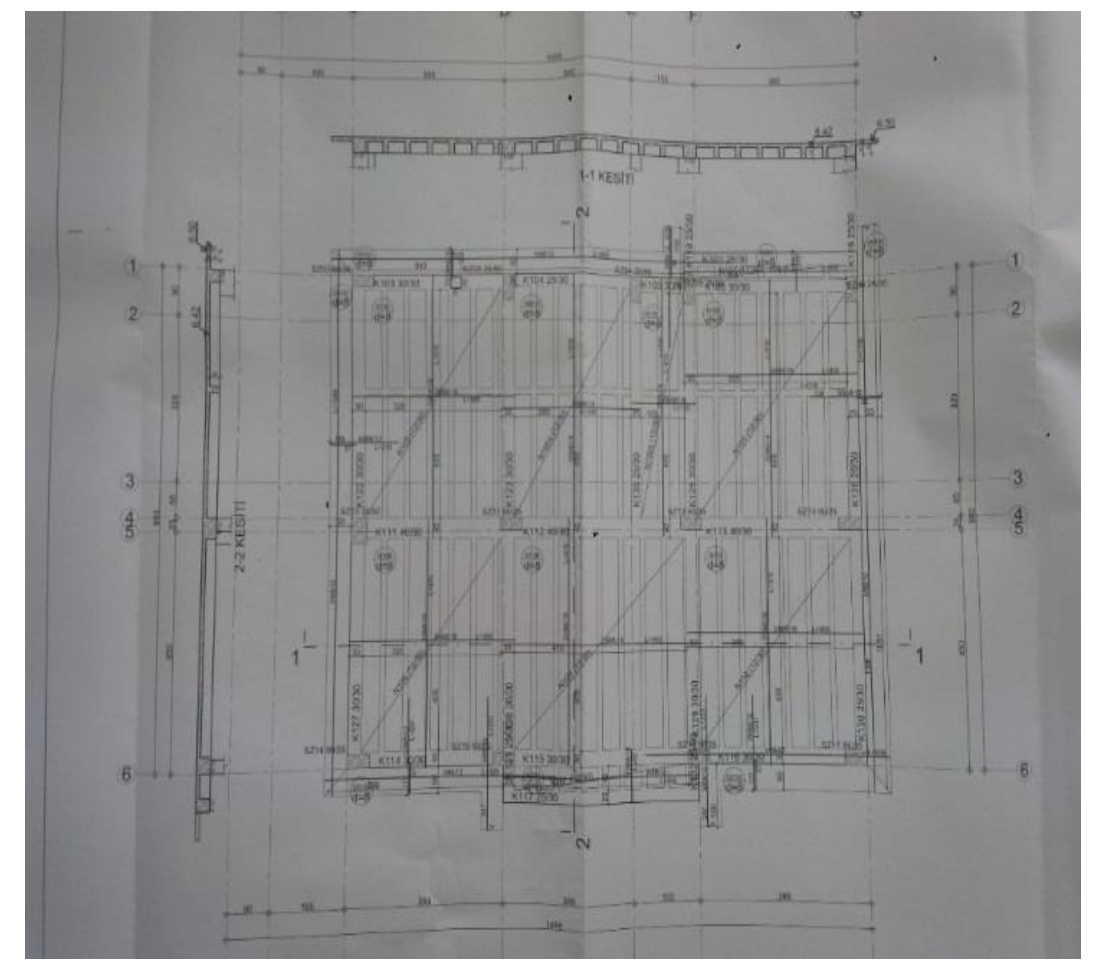

Şekil 1. Perde içermeyen dişli (asmolen) döşemeli bir proje örneği 


\section{Yapılan Çalışmalar Sonucu Elde Edilen Veriler}

\subsection{Hem Projelerde Hem de Yapım Aşamalarında Tespit Edilen Hatalar}

\subsubsection{Yapıların süneklik düzeyleri}

DBYBHY 2007 ve TBDY 2018 yönetmeliklerinde perde içermeyen tek doğrultuda dişli (asmolen) döşemelerin süneklik düzeyi normal/sınırlı sistemler olduğunu bir önceki bölümde incelenmişti. Sakarya genelinde incelenen 40 adet yapının \%12.5'inde bu kurala uyulmamıştır.

\subsubsection{Kolonlarda sarılma bölgesi uzunluğu}

DBYBHY 2007'nin 3.3.4.1. maddesinde, yapısal betonarme kolonların her birinin alt ucunda ve üst ucunda özel sarılma bölgeleri oluşturulması gerektiği belirtilmiştir. Ayrıca, oluşturulacak özel sarılma bölgelerinin her birinin uzunluğu kolon kesitinin büyük boyutundan (dairesel kolonlarda kolon çapından), kolon serbest yüksekliğinin 1/6'sından ve $500 \mathrm{~mm}$ 'den az olamayacağı vurgulanmıştır. Konsol kolonların ise sarılma bölgelerinin kolonun alt ucunda oluşturulacağı ve uzunluğunun da kolon büyük boyutunun iki katından az olamayacağ belirtilmiştir. Kolonun temel içinde kalan kısmında da sarılma bölgesi 300 mm' den ve en büyük boyuna donatı çapının 25 katından az olmayacak bir yükseklik boyunca devam ettirileceği belirtilmiştir

TBDY 2018'in 7.3.4.1. maddesinde de, betonarme kolonların alt ucunda ve üst ucunda özel sarılma bölgeleri oluşturulması gerektiği belirtilmiştir. Özel sarılma bölgelerinin her birinin uzunluğu kolon en büyük kesit boyutunun 1,5 katından, kolon serbest yüksekliğinin 1/6'sından ve $500 \mathrm{~mm}$ 'den az olamayacağı vurgulanmıştır. Konsol kolonların ise sarılma bölgelerinin kolonların alt ucunda oluşturulacağı ve uzunluğunun da kolon büyük boyutunun iki katından az olamayacağı belirtilmiştir. Kolonun temel içinde kalan kısmında da sarılma bölgesi kolonun en küçük kesitinin boyutundan az olmayacak bir yükseklik boyunca devam ettirilecek denilmiştir.

İncelenen 40 adet projenin \%2.5'inde, yapım aşamasında ise \%40'ında bu kurala uyulmadığ görülmüştür (DBYBHY 2007'ye göre).

\subsubsection{Kolonlarda boyuna donatı bindirme boyları}

TS500'de çekme donatısı için kenetlenme boyu (l $\mathrm{l}_{\mathrm{b}}$ (Denklem 4.1)'de gösterilmiştir.

$\mathrm{l}_{\mathrm{b}}=\left(0,12 * \mathrm{f}_{\mathrm{yd}} / \mathrm{f}_{\mathrm{ctd}} * \Phi\right) \geq 20 * \Phi$

DBYBHY 2007'nin 3.3.3.1 maddesinde, kolon boyuna donatılarının bindirmeli eklerinin mümkün olduğunca kolonların orta bölgelerinde yapılması gerektiği vurgulanmıştır. Bu durumda bindirme ekinin boyu (Denklem 4.1)'de verilen kenetlenme boyuna eşit olacağ belirtilmiştir.

TBDY 2018 7.3.3.1. maddesinde, kolonların boyuna donatılarının bindirme eklerinin sadece kolonların serbest yüksekliğinin orta üçte birlik bölgesinde yapılabileceği ve bindirme eki boyunun $l_{b}$ 'den küçük olamayacağ 1 belirtilmiştir. 
İncelenen 40 adet projenin $\% 15$ 'inde, uygulamada ise \%27.5'inde bu kurala uyulmamıştır. Bu projelerde bindirme boyları kenetlenme boyundan daha kısa bırakılmıştır (DBYBHY 2007'ye göre).

\subsubsection{Kirişlerde boyuna donatılar arası minimum mesafe}

TS 500'ün 7.3. maddesine göre; sıra içindeki boyuna donatılar arasındaki net aralığın boyuna donatı çapından, maksimum agrega çapının 4/3'ünden ve $20 \mathrm{~mm}$ 'den daha az olamayacağ belirtilmiştir. Ayrıca donatıların çift sıra veya daha fazla sıra olarak konulması gereken hallerde üst sıradaki donatıların alt sıradakiler ile aynı düşey eksen üzerinde sıralanması ve iki sıra arasındaki mesafenin en az $25 \mathrm{~mm}$ veya donatı çapı kadar olması gerektiği belirtilmiştir.

Çalışma kapsamında incelenen projelerin \%15'inde bu kurallara uyulmamıştır. Bu projelerin tamamında kiriş-kolon veya kiriş-perde mesnet donatıları çok sık yerleştirilmiş gerekli ara mesafeyi sağlamamıştır. Uygulamadaki binaların ise \%60'ında bu kurala uyulmamıştır.

\subsubsection{Kirişlerde boyuna donatıların kenetlenme ve kanca boyları}

DBYBHY 2007'nin 3.4.3.1. maddesinin (b) bendi ve TBDY 2018'in 7.4.3.1. maddesinin (b) bendindeki diğer hususlara göre; kiriş boyuna donatıların kolon içinde kalan yatay kısmı ile 90 derece bükülen düşey kısmının toplam uzunluğunun, Denklem 4.1'de belirtilen düz kenetlenme boyu lb'den az olamayacağı, 90 derece olan kancanın yatay kısmı 0.4 lb'den, düşey kısmı ise $12 \Phi$ 'den az olamayacağı belirtilmiştir. Ayrıca, betonarme perdelerde ve kenar uzunluğu düz kenetlenme boyu $l_{b}$ 'den ve 50Ф'den daha fazla olan kolonlarda, boyuna donatının kenetlenmesinin, 90 derece kanca bükülmeksizin düz olarak sağlanabileceği belirtilmiştir.

DBYBHY 2007 3.4.3.1. maddesinin (c) bendi ve TBDY 2018 7.4.3.1. maddesinin (c) bendine göre ise her iki taraftan kirişler ile kolonların birleşmesi halinde kiriş alt donatılarının, açıklığa komşu olan kolon yüzünden itibaren, 50Ф'den daha az olmamak üzere, en az Denklem 4.1'de verilen kenetlenme boyu $l_{b}$ kadar uzatılacağı belirtilmiştir.

Çalışma kapsamında incelenen projelerin \% 7,5'inda bu kurallara uyulmamıştır. Uygulamadaki binaların ise \%80'inde bu kurallara uymayan en az bir kirişin olduğu gözlemlenmiştir.

\subsubsection{Kolon-kiriş birleşim bölgelerinde enine donatı}

DBYBHY 2007'nin 3.5.2.3. maddesinin (a) bendi ve TBDY 2018'in 7.5.2.3. maddesinin (a) bendine göre, kuşatılmış birleşimlerde, alttaki kolonun sarılma bölgesinde kullanılan enine donatı miktarının en az \%40'ının, birleşim bölgesi boyunca kullanılacağı ve enine donatının çapının 8 mm'den küçük, aralığının da 150 mm'yi aşamayacağı belirtilmiştir.

DBYBHY 2007'nin 3.5.2.3. maddesinin (b) bendi ve TBDY 2018'in 7.5.2.3. maddesinin (b) bendine göre, kuşatılmamış birleşimlerde, alttaki kolonun sarılma bölgesinde kullanılan enine donatı miktarının en az \%60'ının, birleşim bölgesi boyunca kullanılacağı ve enine donatının çapının 8 mm'den küçük, aralığının da 100 mm'yi aşamayacağı belirtilmiştir.

Çalışma kapsamında incelenen projelerin $\% 27,5$ 'inde bu kurallara uyulmadığ 1 görülmüştür. Uygulamadaki binaların ise \%95'inin bu kurala uymadığı gözlemlenmiştir. 


\subsection{7. Çift doğrultuda çalışan döşemelerin kalınlıkları}

TS500'ün 11.4.1. maddesine göre; düzgün yayılı yük taşıyan, dört kenarı boyunca mesnetlenmiş ve uzun kenarının kısa kenarına oranı 2,0 veya daha küçük olan betonarme plaklar iki doğrultuda çalışan plaklar olarak adlandırılır.

TS 500'ün 13.2.1. maddesine göre; kiriş ve özellikle döşemeler sehime duyarlı yapı elemanı taşımıyorsa ve bunlarla ilişiği yoksa, eğilme elemanlarının yüksekliğinin açıklığa oranı, Tablo 1.'de verilen sınırların üzerinde kalması şartı ile sehim hesabının yapılmayabileceği belirtilmiştir.

Tablo 1. Eğilme elemanlarında sehim hesabı gerektirmeyen döşeme (yükseklik/açıklık) oranları (TS5500)

\begin{tabular}{lcccc}
\hline Eleman & Basit Mesnet & Kenar Açıklık & İç Açıklık & Konsol \\
Tek Doğr. Çalışan Döşeme & $1 / 20$ & $1 / 25$ & $1 / 30$ & $1 / 10$ \\
Çift Doğr. Çalışan Döşeme & $1 / 25$ & $1 / 30$ & $1 / 35$ & - \\
Dişli Döşeme & $1 / 15$ & $1 / 18$ & $1 / 20$ & $1 / 8$ \\
Kiriş & $1 / 10$ & $1 / 12$ & $1 / 15$ & $1 / 5$ \\
\hline
\end{tabular}

Çalışma kapsamında incelenen projelerin \%7'sinde bu kurala uyulmadığı gözlemlenmiştir. Uygulamadaki binaların ise \%21'inde bu kurala uyulmadığı görülmüştür. Projesindeki döşeme yüksekliklerinin imalat aşamasında yetersiz olduğu saptanmıştır.

\subsubsection{Tek doğrultuda dişli döşemelerde enine diş kullanımı}

TS500'ün 11.3.2. maddesine göre; tek doğrultuda çalışan dişli döşemelerin açıklıkları 4 m'den daha fazla ise, taşıyıcı dişlere dik, minimum aynı boyutta enine dişler konulması gerektiği, açıklığın 4-7 m arasında olduğu hallerde 1 enine diş, açıklığın 7 m'den fazla olduğu hallerde ise 2 enine diş konulması gerektiği belirtilmiştir. Ayrıca enine dişlerin, açıklığ 1 eşit miktarda bölmesine dikkat edilmesi istenmiştir.

Çalışma kapsamında incelenen projelerin ve uygulamadaki binaların \%50'sinde bu kurala uyulmamıştır. Bu binalarda 4-7 m açıklıkta enine diş kullanılmamıştır.

\subsubsection{Tek doğrultuda dişli döşemelerde enine dişlerin en kesit ve donatı şartları}

Dişli döşemelerde enine dişlerin en kesit ve donatıları en az asal dişlerdekine eşit olması gerektiği yönetmeliklerde belirtilmiştir.

Çalışma kapsamında incelenen projelerin ve uygulamadaki binaların \%8'sinde bu kurala uyulmamıştır.

\subsubsection{Betonarme perdelerde perde uç bölgesi oluşturulması}

DBYBHY 2007'nin 3.6.2.1. maddesinde $\mathrm{H}_{\mathrm{w}} / \mathrm{l}_{\mathrm{w}}>2$,0 olan betonarme perdelerin planda her iki ucunda perde uç bölgeleri oluşturulması gerektiği belirtilmiştir. 3.6.2.2. maddesinde de $\mathrm{H}_{\mathrm{w}}$, temel üstünden veya perdenin plandaki uzunluğunun \%20'den daha fazla küçüldüğü seviyeden 
itibaren ölçülen toplam perde yüksekliği ve $1_{\mathrm{w}}$ de betonarme perdenin plandaki uzunluğu olarak tanımlanmıştır.

TBDY 2018'in 7.6.2.1. maddesinde $\mathrm{H}_{\mathrm{w}} / 1_{\mathrm{w}}>2,0$ olan perdelerin planda her iki ucunda perde uç bölgeleri oluşturulması gerektiği ve uç bölgelerin, perde uç bölgesinin kendi kalınlığı içinde oluşturulabileceği gibi, perdeye birleşen diğer bir perdenin içinde de düzenlenebileceği belirtilmiştir. Burada da $\mathrm{H}_{\mathrm{w}}$, temel üstünden veya perdenin plandaki uzunluğunun \%20'den daha fazla küçüldüğü seviyeden itibaren ölçülen toplam perde yüksekliği ve $1_{\mathrm{w}}$ de betonarme perdenin plandaki uzunluğu olarak tanımlanmıştır.

Çalışma kapsamında incelenen projelerin \%10'unda bu kurala uyulmamıştır. Uygulama aşamasında da perde uç bölgesi oluşturulmamıştır. Yapılan hatalarda projede tasarlanan betonarme perdeye herhangi bir uç bölge oluşturulmamış, bu da deprem yönetmeliğine aykırı bir durum teşkil etmiştir.

\subsubsection{Betonarme perdelerde perde uç bölgesi uzunluğu}

DBYBHY 2007 3.6.2.3. ve TBDY 2018 7.6.2.3. maddelerine göre; dikdörtgen kesite sahip betonarme perdelerin, kritik perde yüksekliği boyunca uç bölgelerinin her birinin plandaki uzunluğu, perdenin plandaki toplam uzunluğunun \%20'sinden ve perde kalınlığının iki katından daha az olamayacağı, kritik perde yüksekliğinin üstünde kalan perde kesimi boyunca ise, perde uç bölgelerinin her birinin plandaki uzunluğunun, perdenin plandaki toplam uzunluğunun \%10'undan ve perde kalınlığından az olamayacağ 2007 hem de TBDY 2018'de kritik perde yüksekliği $\left(\mathrm{H}_{\mathrm{cr}}\right)$ (Denklem 4.2)'deki gibi tanımlanmıştır:

$21_{\mathrm{w}} \geq \mathrm{H}_{\mathrm{cr}} \geq \max \left[1_{\mathrm{w}} ; \mathrm{H}_{\mathrm{w}} / 6\right]$

Çalışma kapsamında incelenen projelerin \%10’unda bu kurala uyulmamıştır.

\subsubsection{Kirişli radye temellerde kiriş yükseklikleri}

DBYBHY 2007'nin 3.4.1.1. maddesinin (b) bendinde kiriş yüksekliğinin tabliye kalınlığının 3 katından ve $300 \mathrm{~mm}$ 'den daha az, kiriş gövde genişliğinin 3,5 katından daha fazla olamayacağ 1 belirtilmiştir. 3.4.1.1. maddesinin (c) bendinde ise kiriş yüksekliğinin, kiriş serbest açıklığının 1/4'ünden daha fazla olamayacağı, aksi durumda kiriş gövdesinin her iki tarafina kiriş yüksekliği boyunca gövde donatısı konulması gerektiği belirtilmiştir.

TBDY 2018'in 7.4.1.1. maddesinin (b) bendinde kiriş yüksekliğinin, tabliye kalınlığının 3 katından ve $300 \mathrm{~mm}$ 'den daha az olamayacağı, bu şarta uymayan elemanların, hesaplarda tabliye elemanları ile birlikte modelleneceği, kiriş gibi donatılacağı, ancak çerçeve kirişi olarak kabul edilmeyeceği belirtilmiştir. Ayrıca, kiriş yüksekliğinin kiriş gövde genişliğinin 3,5 katından fazla olmayacağı belirtilmiştir. 7.4.1.1. maddesinin (c) bendinde ise kiriş yüksekliğinin, kiriş serbest açıklığının 1/4'ünden daha fazla olamayacağı, aksi durumda kiriş gövdesinin her iki tarafına kiriş yüksekliği boyunca gövde donatısı konulması gerektiği belirtilmiştir. 
Çalışma kapsamında incelenen projelerin ve uygulamadaki binaların \%20,5'inde bu kurallara tam anlamıyla uyulmamıştır. Burada yapılan hataların tamamı kiriş yüksekliklerinin gövde kalınlığının 3,5 katından fazla olmasıdır.

\subsubsection{Kirişli radye temellerde kiriş boyuna donatılar arası minimum mesafe}

TS 500'ün 7.3. maddesine göre; sıra içindeki boyuna donatılar arasındaki net aralığın boyuna donatı çapından, maksimum agrega çapının 4/3'ünden ve $20 \mathrm{~mm}$ 'den daha az olamayacağ belirtilmiştir. Ayrıca donatıların çift sıra veya daha fazla sıra olarak konulması gereken hallerde üst sıradaki donatıların alt sıradakiler ile aynı düşey eksen üzerinde sıralanması ve iki sıra arasındaki mesafenin en az $25 \mathrm{~mm}$ veya donatı çapı kadar olması gerektiği belirtilmiştir.

Çalışma kapsamında kirişli radye temele sahip binaların incelenen projelerinin \%0,9'unda bu kurallara uyulmamıştır. Bu projelerin tamamında kiriş-kolon veya kiriş-perde mesnet donatıları çok sık yerleştirilmiş gerekli ara mesafeyi sağlamamıştır. Uygulamadaki binaların ise $\% 70,5$ 'inde bu kurala uyulmamıştır.

\subsubsection{Kirişli radye temellerde kiriş sarılma ve orta bölgelerinde enine donatı aralıkları}

DBYBHY 2007'nin 3.4.4. ve TBDY 2018'in 7.4.4. maddelerine göre; süneklik düzeyi yüksek kirişlerin sarılma bölgelerinde ilk etriyenin kolon yüzüne uzaklığının maksimum $50 \mathrm{~mm}$ olabileceği, etriye aralıklarının kiriş yüksekliğinin 1/4'ünden, en küçük boyuna donatı çapının sekiz katından ve $150 \mathrm{~mm}$ 'den fazla olamayacağı belirtilmiştir.

Kirişli radye temele sahip incelenen projelerin ve uygulamadaki binaların \%73,5'inde bu kurallara uyulmadığı gözlemlenmiştir. Proje aşamalarında temel kirişlerinde sarılma bölgeleri oluşturulmamış etriye aralıkları $200 \mathrm{~mm}$ olarak tasarlanmıştır.

\subsection{Yalnız Yapım Aşamalarında Tespit Edilen Hatalar}

\subsubsection{Enine donatı kanca açıları}

DBHBHY 2007'nin 3.2.8.1. ve TBDY 2018'nin 7.2.8.1. maddelerine göre; özel deprem etriyelerinin her iki ucunda mutlaka 135 derece kıvrımlı kancaların bulunması gerektiği, özel deprem çirozlarında ise bir uçta 90 derece kıvrımlı kanca yapılabileceği belirtilmektedir. $\mathrm{Bu}$ durumda kolonun veya perdenin bir yüzünde, kanca kıvrımlar1 135 derece ve 90 derece olan çirozlar hem yatay hem düşey doğrultuda şaşırtmalı olarak düzenlenebileceği belirtilmiştir.

İncelenen binaların \%80'inde bu kurallara uyulmadığı, etriye kancalarının 90 derece büküldüğü gözlemlenmiştir.

\subsubsection{Enine donatı kolları ve/veya çirozlar arasındaki en büyük mesafe}

DBHBHY 2007'nin 3.3.4.1. maddesinin (a) bendine göre; etriye kollarının ve/veya çirozların arasındaki yatay uzaklığın, $\alpha$, etriye çapının 25 katından fazla olmayacağı ve sürekli dairesel spirallerin adımının, göbek çapının $1 / 5$ 'inden ve $80 \mathrm{~mm}$ 'den fazla olmaması gerektiği belirtilmektedir. 
TBDY 2018 17.4.2.2. maddesine göre ise etriye kollarının ve/veya çirozların arası yatay uzaklık $\alpha$, etriye çapının 25 katından fazla olamayacağı belirtilmiştir.

Çalışma kapsamında incelenen binaların \%85'inde bu kurallara uyulmadığı görülmüştür. Çirozların rastgele montaj edildiği ve ara mesafelerine uyulmadığı gözlemlenmiştir.

\subsubsection{Bitişik nizam binalarda derz bırakılması}

DBYBHY 2007'nin 2.10.3.2. ve TBDY 2018'nin 4.9.3.2. maddelerine göre; bitişik nizam yapılarda bırakılacak minimum derz boşluğunun, $6 \mathrm{~m}$ bina yükssekliğine kadar en az $30 \mathrm{~mm}$ olacağ 1 ve bu değere bina yüksekliği 6 m'den sonraki her 3 m' lik yükseklik için en az $10 \mathrm{~mm}$ daha ekleneceği belirtilmiştir

$\mathrm{Bu}$ çalışma kapsamında incelenen binalardan 2 tanesi farklı yerlerde bitişik nizam olarak inşa edilmiştir. Bu 2 binada da (\%100) bu kurallara uyulmamıştır.

\subsubsection{Enine donatı kanca boyları}

DBYBHY 2007'nin 3.2.8.1. ve TBDY 2018'in 7.2.8.1. maddelerine göre; etriye ve çirozlarda 135 derece kıvrımlı kancaların en az $5 \varnothing$ çaplı daire etrafında büküleceği ve kancaların boylarının kıvrımdaki en son teğet noktasından itibaren, düz yüzeyli çubuklarda $10 \emptyset$ ve 100 mm'den, nervürlü çubuklarda ise $6 \varnothing$ ve 80 mm'den az olamayacağı belirtilmiştir.

Çalışma kapsamında incelenen binaların \%10'unda bu kurala uymayan en az bir yapı elamanı tespit edilmiştir.

\subsubsection{Kolonlarda minimum net beton örtüsü}

TS 500'ün 7.4.1. maddesine göre; kolonların pas payları; dış taraftaki yapı elemanlarında 25 mm'den, iç taraftaki yapı elemanlarında ise $20 \mathrm{~mm}$ 'den daha az olmamalıdır.

İncelenen binaların \%45'inde bu kurala uyulmadığı görülmüştür. Uygun olmayan bu yapılarda imalat aşamasında beton örtüsü oluşturacak pas payı aparatlarının hiç kullanılmadığı beton dökümünden sonra bazı donatıların beton yüzeyinde göründükleri gözlemlenmiştir.

\subsubsection{Kolonlarda sarılma ve orta bölgesinde enine donatı aralıkları}

DBYBHY 2007'nin 3.3.4.1. maddesinin (a) bendine göre; kolon sarılma bölgesinde $\emptyset 8$ 'den daha düşük çapa sahip enine donatı kullanılamayacağı, bu bölgelerde boyuna doğrultudaki etriye ve çiroz aralığının en küçük en kesit boyutunun 1/3'ünden ve $100 \mathrm{~mm}$ 'den daha fazla, 50 mm'den de daha az olamayacağı belirtilmiştir.

TBDY 2018'in 7.3.4.1. maddesinin (a) bendine göre; kolon sarılma bölgelerinde $\emptyset 8$ 'den daha düşük çapa sahip enine donatı kullanılamayacağı, bu bölgelerde boyuna doğrultudaki etriye ve çiroz aralığının en küçük kesit boyutunun 1/3 ünden, 150 mm'den ve boyuna donatı çapının altı katından daha büyük, 50 mm'den daha küçük olamayacağı belirtilmiştir

DBYBHY 2007'nin 3.3.4.2. ve TBDY 2018'in 7.3.4.2. maddelerinde de, kolon orta bölgelerinde $\emptyset 8$ 'den daha düşük çapa sahip enine donatı kullanılamayacağı, bu bölgelerde 
kolon boyunca etriye, çiroz veya spiral aralığının, en küçük en kesit boyutunun yarısından ve $200 \mathrm{~mm}$ 'den daha fazla olamayacağı belirtilmiştir.

İncelenen binaların \%55'inde en az bir kolonda bu kurallara uyulmadığı görülmüştür.

\subsubsection{Kiriş boyuna donatılarının kenar kolon içerisine 90 derece bükülmesi}

DBYBHY 2007'nin 3.4.3.1 maddesinin (b) bendi ve TBDY 2018 7.4.3.1 maddesinin (b) bendine göre; kolon ile birleşen kirişlerin kolonun diğer yüzünde devam etmediği durumlarda kirişlerdeki alt ve üst donatı, kolonun etriyelerle sarılmış çekirdeğinin karşı taraftaki yüzeyine kadar uzatılıp etriyelerin iç tarafından 90 derece büküleceği belirtilmiştir.

İncelenen binaların \%20'sinde bu kurala uymayan en az bir temel kirişi olduğu gözlemlenmiştir. Donatılar kolon içerisinde düz olarak bırakılmıştır.

\subsubsection{Kirişlerin sarılma ve orta bölgelerinde enine donatı aralıkları}

DBYBHY 2007'nin 3.4.4. ve TBDY 2018'in 7.4.4. maddelerine göre; süneklik düzeyi yüksek kirişlerin sarılma bölgelerinde ilk etriyenin kolon yüzüne uzaklığının maksimum $50 \mathrm{~mm}$ olabileceği, etriye aralıklarının kiriş yüksekliğinin 1/4'ünden, en küçük boyuna donatı çapının sekiz katından ve $150 \mathrm{~mm}$ 'den fazla olamayacağı belirtilmiştir.

TS500'ün 7.4.1. maddesine göre ise kiriş orta bölgelerinde enine donatı aralığının en küçük boyuna donatı çapının 12 katından ve $200 \mathrm{~mm}$ 'den fazla olamayacağı belirtilmiştir.

İncelenen binaların \%55'inde bu kurallara uymayan en az bir kirişin olduğu gözlemlenmiştir.

\subsubsection{Kirişlerde net beton örtüsü}

TS500'ün 7.3. maddesine göre; kirişlerde net beton örtüsü kalınlığının özel yapılar dışında, dış taraftaki yapı elemanlarında $25 \mathrm{~mm}$ 'den, iç taraftaki yapı elemanlarında $20 \mathrm{~mm}$ 'den daha az olamayacağı, çevre koşullarının çok daha elverişsiz olduğu durumlarda ve daha fazla yangın güvenliğine ihtiyaç duyulan durumlarda ise bu kalınlıkların artırılması gerektiği belirtilmiştir.

İncelenen binaların \%65'inde bu kurallara uymayan en az bir kirişin olduğu gözlemlenmiştir. Kalıp ve donatı imalatı sırasında pas payı aparatı kullanılmamış ve donatı beton örtüsüyle kaplanmamıştır. Daha sonra sıva imalatıyla kapatılsa bile ileriki zamanlarda donatının korozyona uğraması kaçınılmazdır.

\subsubsection{Kirişlerde sarılma bölgesi uzunluğu}

DBYBHY 2007'nin 3.4.4. ve 3.8.4. maddeleri ile TBDY 2018'in 7.4.4. ve 7.8.4. maddelerinde, süneklik düzeyi yüksek ve süneklik düzeyi normal/sınırlı kirişlerde, kiriş mesnetlerinde kolon yüzünden başlanarak kiriş yüksekliğinin minimum 2 katı kadar uzunluğundaki bölge sarılma bölgesi olarak tanımlanmış ve etriye sıklaştırılması ile bu bölgenin oluşturulması zorunlu kılınmıştır.

İncelenen binaların \%75'inde bu kurallara uymayan en az bir kirişin olduğu gözlemlenmiştir. $\mathrm{Bu}$ kirişlerde sarılma bölgeleri oluşturulmamış ya da yetersiz bırakılmıştır. 


\subsubsection{Döşemelerde net beton örtüsü kalınlığı}

TS 500'ün 11.2.2. ve 11.4.2. maddelerinde tek doğrultuda ve çift doğrultuda çalışan plak döşemelerde donatıyı saran ve koruyan net beton örtüsünün minimum $15 \mathrm{~mm}$ olması gerektiği belirtilmiştir.

İncelenen binaların \%71'inde bu kurala uyulmadığı görülmüştür. Uygunsuz imalatlarda imalat aşamasında hiçbir pas payı elemanı kullanılmamış donatılar kalıp yüzeyine konulmuştur.

\subsubsection{Tek doğrultuda çalışan kirişli döşemelerin döşeme kalınlıkları}

TS 500'ün 13.2.1. maddesine göre; kiriş ve özellikle döşemeler sehime duyarlı yapı elemanı taşımıyorsa ve bunlarla ilişiği yoksa, eğilme elemanlarının yüksekliğinin açıklığa oranı, Tablo 3.1.'de verilen sınırların üzerinde kalması şartı ile sehim hesabının yapılmayabileceği belirtilmiştir.

İncelenen binaların \%14'ünde bu kurala uymayan, projesindeki döşeme yüksekliğini sağlamayan en az bir döşeme elemanı olduğu gözlemlenmiştir.

\subsubsection{Tek doğrultuda çalışan kirişli döşemelerin çekme donatısı aralıkları}

TS500'ün 11.2.3. maddesine göre; tek doğrultuda çalışan döşemelerde asal (çekme) donatı aralığı döşeme kalınlığının 1,5 katından ve 200 mm'den fazla olamayacağ

İncelenen binaların \%21'inde bu kurala uymayan, projesindeki çekme donatısı aralığını sağlamayan en az bir tane tek doğrultuda döşeme elemanı olduğu gözlemlenmiştir.

\subsubsection{Tek doğrultuda dişli (asmolen) döşemelerin dağıtma donatısı aralıkları}

TS 500'ün 11.3.3. maddesine göre; dişli döşemelerde dişlerin üstündeki tabliyede, her iki doğrultuda dağıtma donatısı bulundurması, bu donatı miktarının her bir doğrultuda plak tüm kesit alanının 0,0015 den az, donatı aralığının ise $250 \mathrm{~mm}$ 'den fazla olmaması gerektiği belirtilmiştir

Tek doğrultuda dişli (asmolen) döşemeye sahip incelenen binaların \%83'ünün bu kurala uyulmadığı gözlemlenmiştir.

\subsubsection{Tek doğrultuda dişli (asmolen) döşemelerde dişlerin enine donatı aralıkları}

TS 500'ün 11.3.3. maddesine göre; dişli döşemelerde dişler için enine donatı aralığının 250 mm’yi geçmemesi gerektiği belirtilmiştir.

İncelenen binaların \%33’ünde bu kurala uymayan en az bir diş olduğu gözlemlenmiştir.

\subsubsection{Betonarme perdelerin yatay gövde donatıları}

DBYBHY 2007'nin 3.6.3.1. ve TBDY 2018 7.6.3.1. maddelerinde perde gövdelerinde enine donatı aralıklarının 250 mm'yi geçmemesi gerektiği belirtilmiştir. 
İncelenen binaların \%10'unda bu kurala veya projesindeki ölçüsüne uymayan en az bir tane betonarme perde eleman olduğu gözlemlenmiştir.

\subsubsection{Betonarme perdelerin düşey gövde donatıları}

DBYBHY 2007'nin 3.6.3.1. ve TBDY 2018 7.6.3.1. maddelerinde perde gövdelerinde düşey donatı aralıklarının 250 mm'yi geçmemesi gerektiği belirtilmiştir.

TS 500'ün 12.3. maddesinde ise perde gövdesinde düşey donatı aralıklarının, duvar kalınlığının 1,5 katından ve $300 \mathrm{~mm}$ 'den fazla olamayacağı belirtilmiştir.

İncelenen binaların \%6,5'inde bu kurala veya projesindeki ölçüsüne uymayan en az bir tane betonarme perde eleman olduğu gözlemlenmiştir.

\subsubsection{Betonarme perdelerde çiroz kullanımı}

DBYBHY 2007'nin 3.6.3.3. ve TBDY 2018'in 7.6.3.3. maddelerine göre; perde uç bölgeleri dışında, perde gövdelerinin her iki yüzünde yer alan donatı ağlarının, beher metrekare perde yüzünde minimum 4 adet özel deprem çirozu kullanılarak karşılıklı olarak bağlanması gerektiği, kritik perde yüksekliği boyunca ise uç bölgeleri dışındaki beher metrekare perde yüzünde minimum 10 adet özel deprem çirozu kullanılması gerektiği belirtilmiştir. Ayrıca çirozların çapının, en az yatay donatının çapı kadar olması gerektiği belirtilmiştir.

DBYBHY 2007'de çirozların yatay donatılardan bağımsız olarak düşey donatıları karşılıklı olarak sarması istenirken, TBDY 2018'de çirozların hem yatay hem de düşey donatıları içine alacak şekilde karşılıklı sarması istenmiştir (Şekil 2).

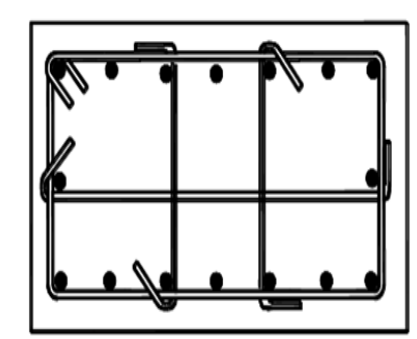

a) TBDY 2018 e göre

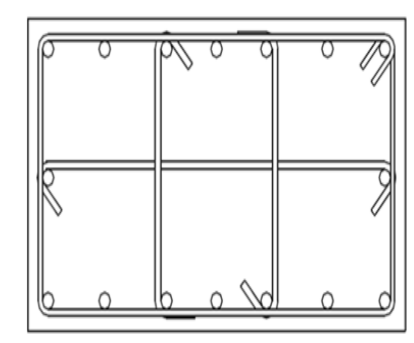

b) DBYBHY 2007'ye göre

Şekil 2. TBDY 2018 ve DBYBHY 2007'ye göre özel deprem çirozlarını bağlama şekli

İncelenen binaların \%74'ünde bu kurallara uymayan en az bir betonarme perde eleman olduğu gözlemlenmiştir.

\subsubsection{Temellerde net beton örtüsü kalınlığı}

TS 500'ün 10.1. maddesine göre; temellerde net beton örtüsünün 50 mm'den az olamayacağ belirtilmiştir. 
İncelenen binaların \%83'ünde bu kurala uyulmamıştır. Uygulama esnasında herhangi bir pas payı ekipmanının kullanılmadığı, donatıların grobeton üzerine bırakıldığ 1 veya mermer vb. yetersiz malzemeler kullanıldığı gözlemlenmiştir.

\subsubsection{Kirişli radye temellerde kiriş boyuna donatıların kenar kolonlara 90 derece bükülmesi}

DBYBHY 2007'nin 3.4.3.1 maddesinin (b) bendi ve TBDY 2018 7.4.3.1 maddesinin (b) bendine göre; kolon ile birleşen kirişlerin kolonun diğer yüzünde devam etmediği durumlarda kirişlerdeki alt ve üst donatı, kolonun etriyelerle sarılmış çekirdeğinin karşı taraftaki yüzeyine kadar uzatılıp etriyelerin iç tarafından 90 derece büküleceği belirtilmiştir.

Temeli kirişli radye olan incelenen binaların \%56'sında bu kurala uymayan en az bir temel kiriş olduğu gözlemlenmiştir. Donatılar kolon içerisinde düz olarak bırakılmıştır.

\subsubsection{Kirişli radye temellerde kiriş boyuna donatıların kenetlenme ve kanca boyları}

DBYBHY 2007'nin 3.4.3.1. maddesinin (b) bendi ve TBDY 2018'in 7.4.3.1. maddesinin (b) bendindeki diğer hususlara göre; kiriş boyuna donatıların kolon içinde kalan yatay kısmı ile 90 derece bükülen düşey kısmının toplam uzunluğunun, Denklem 4.1'de belirtilen düz kenetlenme boyu lb'den az olamayacağı, 90 derece olan kancanın yatay kısmı 0.4 lb'den, düşey kısmı ise $12 \Phi$ 'den az olamayacağı belirtilmiştir. Ayrıca, betonarme perdelerde ve kenar uzunluğu düz kenetlenme boyu lb'den ve 50 $\Phi$ 'den daha fazla olan kolonlarda, boyuna donatının kenetlenmesinin, 90 derece kanca bükülmeksizin düz olarak sağlanabileceği belirtilmiştir.

DBYBHY 2007 3.4.3.1. maddesinin (c) bendi ve TBDY 2018 7.4.3.1. maddesinin (c) bendine göre ise her iki taraftan kirişler ile kolonların birleşmesi halinde kiriş alt donatılarının, açıklığa komşu olan kolon yüzünden itibaren, 50Ф'den daha az olmamak üzere, en az Denklem 3.1'de verilen kenetlenme boyu $l_{b}$ kadar uzatılacağı belirtilmiştir.

Temeli kirişli radye olan incelenen binaların \%100'ünde bu kurala uymayan en az bir temel kiriş olduğu gözlemlenmiştir. Donatıların kenetlenme boyları ve kanca boyları yetersiz bırakılmıştır.

\section{Sonuçlar}

Sakarya genelinde incelenen rastgele seçilmiş 40 adet yapının proje ve imalat hataları bir önceki bölümde açıklanmıştı. Literatürde daha önce Ankara, Balıkesir, Trabzon, Yalova ve Kocaeli illerinde de benzer çalışma yapılmıştır.

Genel olarak hata oranlarına baktığımızda oldukça yüksek oranlar olduğunu görmekteyiz. Biz inşaat mühendislerinin bir nevi anayasası gibi olan deprem yönetmeliklerine bu denli aykırı ve hatalı imalatlar sonucu yapılan binalar, hala deprem bilincine tam manasıyla ulaşamadığımızı gösteriyor. Projelendirme aşaması ne kadar kusursuz olursa olsun eğer uygulamada yönetmelik şartları ve proje koşulları sağlanmıyorsa bu hiçbir anlam ifade etmez. Önemli bir deprem ülkesi olmamız ve yüksek oranda hatalı bina stokuna sahip olmamız gelecekte yaşanabilecek depremlerde can ve mal kaybı olarak bize geri dönecektir. Bu konuda bizlere önemli görevler 
düşmektedir. Şunu tam manasıyla anlamalıyız ki deprem değil, tekniğine uygun yapılmamış hatalı binalar can ve mal kayıplarına neden olur.

Öncelikle deprem yönetmeliklerine tam manasılla hakim olmalı ve buna göre yapıları projelendirmeliyiz. Projelerin yapı denetim firmaları ve belediyelerde çok fazla kontrol edilmediği anlaşılmaktadır. Projelerin yetkin mühendislik belgesine sahip mühendisler tarafından tasarlanıp onaylanması aşikardır. Kontrol aşamasında ise yapı denetim ve belediyelerin daha etkin olması, bunun yanı sıra her ilde projelerin öncelikle inşaat mühendisleri odalarından onay almaları daha uygun olacaktır. Bu şekilde proje aşamasında yapılacak hatalar minimuma indirilebilir. Uygulama aşamasında ise yapı denetim firmalarına ve şantiye şeflerine (Mühendislerine) büyük görevler düşmektedir. Yapı denetim firmaları genellikle yeni mezun inşaat mühendisleri çalıştırdığı için mezun olmadan önce üniversitelerde son sınıflara yönetmelikle alakalı seçmeli dersler konularak bu konuda yaşanabilecek sıkıntılar azaltılabilir. Yine yapı denetim firmaları imalat kontrollerini sahada sıkı bir şekilde yapmalı, hatalı ve eksik imalatları düzelttirmeli, üstlendiği kontrol vazifesini kötü amaçlar için kullanmamalıdır. Şantiye şeflerinin de şantiyelerde etkin rol almaları, sadece kâğıt üstünde imza karşılı̆̆ında bu işi üstlenmemeleri gerekir. Şantiye mühendislerinin şantiyelerde yapılan her imalatı anında kontrol etmeleri, varsa gerekli düzeltmeleri yaptırmaları gerekmektedir.

En önemli eksikliklerden birisi de şantiyelerde çalışan inşaat işçilerinin gerekli donanıma ve mesleki yeterliliğe sahip olmamalarıdır. Bu konuda kalifiye eleman yetiştirilmesi amacıyla inşaat işçilerine mesleki eğitim kurslarının verilmesi, kulaktan dolma bilgilerle değil tekniğine göre imalatların yapılmasının anlatılması ve sonunda da mesleki eğitim sertifikalarının verilmesi bir çözüm olacaktır. İlgili kurumlar tarafından inşatta çalışan işçilerin sertifika kontrolü yapılmalıdır. Bu sayede daha bilinçli işçiler görev alacak, imalat hataları minimuma inecektir.

\section{Kaynakça}

TBDY 2018, Türkiye Bina Deprem Yönetmeliği 2018.

DBYBHY 2007, Deprem Bölgelerinde Yapılacak Binalar Hakkında Yönetmelik 2007.

TS 500, Türk Standartları 500 - Betonarme Yapıların Tasarım ve Yapım Kuralları.

Çalık, Ç., Deprem Bölgelerinde Yapılacak Binalar Hakkında Yönetmelik 2007 Sonrası Yapıların Proje ve Yapım Aşamalarında Karşılaşılan Hatalar Üzerine İnceleme - Trabzon Merkez Örneği, KTÜ Yüksek Lisans Tezi, Fen Bilimleri Enstitüsü, Trabzon 2009.

Geçici, S., Deprem Bölgelerinde Yapılacak Binalar Hakkında Yönetmelik 2007 Sonrası Yapıların Proje ve Yapım Aşamalarında Karşılaşılan Hatalar Üzerine İnceleme Balıkesir(Ayvalık) Örneği, KTÜ Yüksek Lisans Tezi, Fen Bilimleri Enstitüsü, Trabzon 2009.

Lort, Z., Deprem Bölgelerinde Yapılacak Binalar Hakkında Yönetmelik 2007 Sonrası Yapıların Proje ve Yapım Aşamalarında Karşılaşılan Hatalar Üzerine İnceleme - Ankara (EtimesgutSincan) Örneği, KTÜ Yüksek Lisans Tezi, Fen Bilimleri Enstitüsü, Trabzon 2008. 
Mergen, K.,Y., Deprem Bölgelerinde Yapılacak Binalar Hakkında Yönetmelik 2007 Sonras1 Yapıların Proje ve Yapım Aşamalarında Karşılaşılan Hatalar Üzerine İnceleme - Yalova Örneği, SAÜ Yüksek Lisans Tezi, Fen Bilimleri Enstitüsü, Sakarya 2015.

Bozkurt, B., Deprem Bölgelerinde Yapılacak Binalar Hakkında Yönetmelik 2007 Sonras1 Yapıların Proje ve Yapım Aşamalarında Karşılaşılan Hatalar Üzerine İnceleme - Kocaeli Örneği, SAÜ Yüksek Lisans Tezi, Fen Bilimleri Enstitüsü, Sakarya 2015.

Ersan Yapı Denetim Limited Şirketi, Proje arşivi. 